\title{
Effective Average Tax Rates for Permanent Investment
}

Alexander Klemm 



\title{
IMF Working Paper
}

Fiscal Affairs Department

\section{Effective Average Tax Rates for Permanent Investment}

\author{
Prepared by Alexander Klemm
}

Authorized for distribution by Isaias Coelho

March 2008

\begin{abstract}
This Working Paper should not be reported as representing the views of the IMF. The views expressed in this Working Paper are those of the author(s) and do not necessarily represent those of the IMF or IMF policy. Working Papers describe research in progress by the author(s) and are published to elicit comments and to further debate.

This paper extends the effective average tax rate (EATR) developed in Devereux and Griffith (2003) by relaxing the assumption of a one-period perturbation in the capital stock. Instead it allows a permanent investment. While this may appear a small change, it has important implications. First, it allows the EATR to be calculated in the presence of tax holidays, which are an important part of tax systems, especially in developing countries. Second, it reveals an interesting feature of the original EATR: despite the assumption of a one-period investment, the original measure is informative about long-term investments, thanks to the assumption of pooled depreciation. Without this assumption - which is justifiable in a few countries onlythe EATR based on one-period perturbation in the capital stock would be less useful for analyzing medium and long-term investments.
\end{abstract}

JEL Classification Numbers:H25.

Keywords: effective tax rates, discrete investment, tax holidays.

Author's E-Mail Address:aklemm@imf.org 


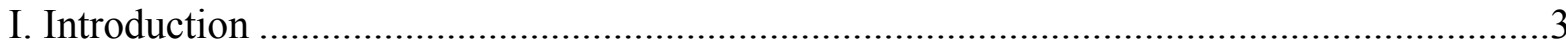

II. Effective Tax Rates for a One-Period Investment ...................................................4

III. Extension to a Permanent Investment.......................................................................... 7

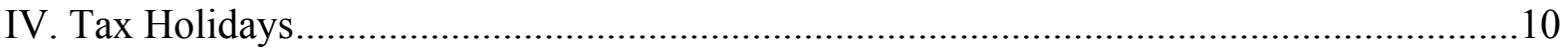

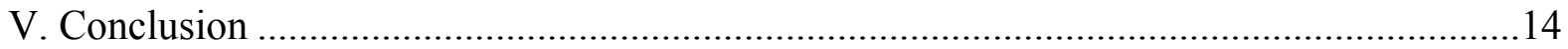

Tables

1. Effective Tax Rates in Selected Advanced Economies, 2005,

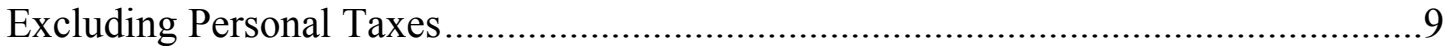

2. Effective Tax Rates in Selected Advanced Economies, 2005,

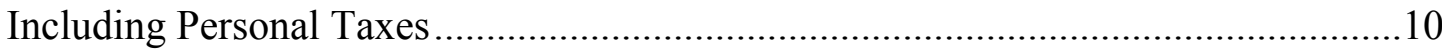

Figures

1. Effective Tax Rates Under Tax Holidays .......................................................................12

2. Tax Holidays Versus a Cash Flow Tax.....................................................................13

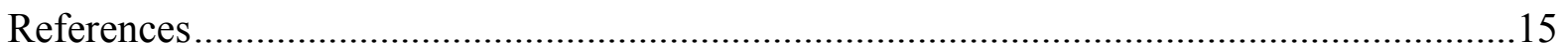




\section{INTRODUCTION}

The effective average tax rate (EATR), as developed in Devereux and Griffith (2003) has proved a popular measure of capital taxation, both in academic research and policy analysis. Its great strengths include that it is based on tax laws and thus forward-looking, and that it is defined for any level of pre-tax profits, thus encompassing the effective marginal tax rate (EMTR, see King and Fullerton, 1984) as a special case, when the post-tax economic profit is exactly zero. As every tax measure, it also has its weaknesses. Notably, it cannot include every important tax law and may thus be misleading about the incentives faced by any particular firm. The purpose of this paper, however, is not to discuss the general merits of different tax measures, as this is done in a range of other papers. ${ }^{1}$

Instead, this paper focuses on one particular characteristic of effective tax rates that is often ignored in their interpretation. This is the fact that the Devereux-Griffith EATR is calculated for a one-period perturbation of the capital stock, which raises the following issues:

- How relevant is a tax rate based on a one-period investment in the analysis of permanent investment decisions? To the extent that countries may be particularly interested in attracting long-term investment, effective tax rates based on short-term investment may not appear to be useful. As it turns out, the specific way in which the Devereux-Griffith tax rate is defined, in particular the treatment of any gains from selling the asset after one period, mean that the Devereux-Griffith tax rate is a useful measure of the taxation of long rather than short term investment, despite the assumption of a one period capital perturbation.

- The assumption of a one-period investment makes it impossible to look at the effects of tax holidays or temporarily reduced rates. As these are extremely common, especially in developing countries and emerging markets, an extension to longerhorizons is warranted.

This short paper is structured as follows. Section B provides a brief description of the Devereux-Griffith effective tax rates. It explains the assumption of a one-period capital perturbation and the treatment of gains achieved when selling assets after one period, and derives an alternative EATR under a different treatment of such gains. Section C extends the original EATR to an investment with an infinite horizon, discusses the conditions under which this change affects EATRs and gives an example of how effective tax rates may differ in practice based on the approach chosen. Section D illustrates the usefulness of infinitehorizon EATRs by using them to calculate the effect of a tax holiday. Section E concludes.

\footnotetext{
${ }^{1}$ These include Nicodeme (2001), OECD (2001), Devereux (2004), and Devereux and Klemm (2004).
} 


\section{EFFECTIVE TAX RATES FOR A ONE-PERIOD INVESTMENT}

\section{The Devereux-Griffith EATR}

While EATRs can sometimes be confusing to policy makers, the basic principle of the Devereux-Griffith EATR is very intuitive. It is defined as the ratio of the present discounted value of taxes over the present discounted value of the profit of a project in the absence of taxation:

$$
\mathrm{EATR}=\frac{R^{*}-R}{p /(1+r)}
$$

where $R *$ is the present discounted value of the economic rent earned in the absence of taxation, $R$ is the same in the presence of taxation, $p$ is the pre-tax net profit and $r$ is the real interest rate. ${ }^{2}$

The present discounted value of the economic rent earned from an investment must be equivalent to the change in the value $(V)$ of the firm:

$$
R=d V_{t}=\sum_{s=0}^{\infty} \frac{\gamma d D_{t+s}-d N_{t+s}}{(1+\rho)^{s}}
$$

where $D$ are dividends, $\gamma=\left(1-m^{d}\right) /(1-z)$ is a factor measuring the difference in treatment of new equity and distributions, with $m^{d}$ the personal tax on dividends and $z$ the tax on capital gains, $N$ stands for new equity issues and $\rho=\left(1-m^{i}\right) i$ is the investor's discount rate, with $m^{i}$ the personal tax rate on interest and $i$ the nominal interest rate. Dividends are determined by the flow of funds equation:

$$
D_{t}=Q\left(K_{t-1}\right)(1+\pi) K_{t-1}(1-\tau)-I_{t}+B_{t}-(1+i(1-\tau)) B_{t-1}+\tau \phi\left(I_{t}+K_{t-1}^{T}\right)+N_{t}
$$

Where $Q\left(K_{t-1}\right)$ is output based on capital $K$ in the previous period, $\tau$ is the corporate tax rate, $I$ is the investment undertaken, $B$ is new debt issued, $\phi$ is the official depreciation allowance, and $K^{T}$ is the tax-written-down value of capital, which follows a simple path: $K_{t}^{T}=(1-\phi) K_{t}^{T}+I_{t}$. Note one important implication of this specification: If an asset is sold, say after one year, at a price that is different from its tax-written down value, then this difference will not be taxed immediately, but instead over time through a permanently lower tax-written-down capital. This assumption is thus equivalent to pooled depreciation, as used in the U.K., where firms depreciate the pooled value of all plant and machinery. For countries, in which firms are required to depreciate each asset separately and where any excess depreciation is taxed at the time of sale, this specification is not realistic.

\footnotetext{
${ }^{2}$ While the numerator is conceptually defined for any project, the denominator already reveals the assumption of a one-period perturbation of the capital stock, as only profits in one period are considered.
} 
Consider first the EATR under finance by retained earnings $(\mathrm{d} B=\mathrm{d} N=0)$. Devereux and Griffith assume an investment of one unit of capital $\left(d I_{t}=1\right)$. This yields an additional financial profit in one period $\left(d Q\left(K_{t}\right)=p+\delta\right)$ and is then sold at its remaining value $\left(d I_{t+1}=-(1-\delta)(1+\pi)\right)$, where $\delta$ is true economic depreciation and $\pi$ is inflation.

Substituting these assumptions into equations (3) and (2), and using a superscript of $R E$ to indicate retained earnings yields:

$$
\begin{aligned}
R^{R E} & =\sum_{s=0}^{\infty} \gamma \frac{d D_{t+s}}{(1+\rho)^{s}} \\
& =\gamma\left[\sum \frac{d Q\left(K_{t-1+s}\right)(1-\tau)}{(1+\rho)^{s}}-\sum \frac{d I_{t+s}}{(1+\rho)^{s}}+\tau \phi \sum \frac{d I_{t+s}^{T}+d K_{t-1+s}^{T}}{(1+\rho)^{s}}\right] \\
& =-\gamma(1-A)+\frac{\gamma}{1+\rho}((p+\delta)(1+\pi)(1-\tau)+(1-\delta)(1+\pi)(1-A))
\end{aligned}
$$

where $A$ is the present discounted value of depreciation allowances, which can be calculated for any depreciation scheme. ${ }^{3}$ In case of finance by new equity $(N E)$ or debt $(D)$, additional financial effects need to be added to equation (4). As derived by Devereux and Griffith they are: $F^{N E}=\frac{-\rho(1-\gamma)}{1+\rho}(1-\phi \tau)$ and $F^{D}=\frac{\gamma(1-\phi \tau)}{1+\rho}(\rho-i(1-\tau))$.

In the absence of taxation, the rent simplifies to:

$$
R^{*}=-1+\frac{(1+\pi)(p+\delta)+(1+\pi)(1-\delta)}{1+i}=\frac{p-r}{1+r}
$$

This allows to calculate the EATR for any level of net profit $p .{ }^{4}$ The special case of the EMTR is obtained by setting the post-tax rent $R$ to zero and solving for the corresponding cost of capital (i.e., the for $p$, which is then marked by a tilde):

${ }^{3}$ In case of declining balance depreciation $A=\tau \phi \frac{1+\rho}{\rho+\phi}$, in case of straight-line depreciation $A=\frac{\tau \phi(1+\rho)}{\rho}\left(1-\left(\frac{1}{1+\rho}\right)^{1 / \rho}\right)$

${ }^{4}$ Putting it all together gives an unwieldy result: $\mathrm{EATR}=\frac{p-r}{p}-\frac{\gamma(1+r)(p+\delta)(1+\pi)(1-\tau)}{p(1+\rho)}+\frac{\gamma(1-A)(1+r)}{p}\left(1-\frac{(1-\delta)(1+\pi)}{1+\rho}\right)-\frac{F(1+r)}{p}$. 


$$
\tilde{p}=\frac{(1-A)(\rho+\delta(1+\pi)-\pi)}{(1+\pi)(1-\tau)}-\frac{F(1+\rho)}{\gamma(1+\pi)(1-\tau)}-\delta
$$

Substituting this into the equations above yields the EMTR. It can also easily be shown that the EMTR simplifies to $(\tilde{p}-r) / \tilde{p}$.

\section{A different assumption on taxation of excess depreciation ${ }^{5}$}

The assumption of pooled depreciation does not hold in all countries. Instead some countries require excess depreciation on sold assets to be refunded. One mechanism is to tax the difference between the price achieved and the tax-written down value. ${ }^{6}$ This can be incorporated very easily into the model by adding a term reflecting such taxation to equation (3):

$$
D_{t}=Q\left(K_{t-1}\right)(1-\tau)-I_{t}+B_{t}-(1+i(1-\tau)) B_{t-1}+\tau \phi\left(I^{T}+K_{t-1}^{T}\right)+N_{t}+\tau\left(I_{t}-I_{t}^{T}\right)
$$

Where $I_{t}^{T}$ is investment for tax purposes, which unlike before, may differ from actual investment. Specifically, in the second period, disinvestment for tax purposes $\left(I_{t+1}^{T}=-(1-\phi)\right)$ will differ from actual disinvestment $\left(I_{t+1}=-(1-\delta)(1+\pi)\right)$, unless the official depreciation allowance accurately reflects net depreciation. As any excess depreciation is now taxed immediately, the calculation of the after-tax rent is simplified tremendously and does not depend anymore on future periods. Substituting these new assumptions into equations (7) and (2) yields the alternative after-tax rent:

$$
R_{n p}=-\gamma(1-\tau \phi)+\frac{\gamma}{1+\rho}((1+p)(1+\pi)(1-\tau)+\tau(1-\phi))+F
$$

where subscript $n p$ indicates that depreciation is not pooled. Financial effects are unaffected by this. While this extension makes the EATR more realistic for some countries, it aggravates the problems caused by the assumption of a one-period perturbation of the capital stock, because the assumption of pooled depreciation meant that firms benefited from generous depreciation rules even if they did not keep the asset, and therefore a long-term effect of these rules was included in EATR. However, to the extent that the depreciation assumption may not have been realistic for many countries, a better way may be to allow permanent investments explicitly.

\footnotetext{
${ }^{5}$ This was previously developed in Klemm (2007), combined with an extension for an allowance for corporate equity.

${ }^{6}$ Many variants are possible, such as relief for inflationary gains, reduced tax rates for long holding periods, rollover-relief in case of reinvestment in capital replacement etc. Any of these assumptions will yield a different EATR, but all will differ substantially from the one based on pooled depreciation.
} 


\section{Extension to A Permanent Investment}

Instead of assuming a one-period perturbation of the capital stock, one could define an EATR for any other investment path. Here we take the simplest approach by assuming an investment that is never sold (i.e., $\left.d I_{t}=1, d I_{t+s}=0 \forall s \geq 1\right){ }^{7}$ Hence only depreciation will reduce the amount of productive capital. Apart from allowing an explicit analysis of longterm investment, this approach has the advantage of removing the question of the appropriate treatment of how excess depreciation is taxed in a sale.

To adapt the EATR to an infinite investment horizon, the denominator of (1) needs to be changed to take account of profits in all future periods. We assume that the net profit rate on capital remains constant at $p$, but that the capital stock declines yearly by the true economic depreciation rate:

$$
\mathrm{EATR}=\frac{R^{*}-R}{p /(r+\delta)}
$$

Equivalently the present discounted value of the rent in the absence of taxation needs to be adapted to: $R^{*}=(p-r) /(r+\delta)$.

To obtain the rent in the presence of taxation for retained earnings, the new assumptions are substituted into (3) and (2), which gives:

$$
R^{R E}=\gamma\left(\sum_{s=1}^{\infty} \frac{(p+\delta)(1-\tau)(1+\pi)^{s}(1-\delta)^{s-1}}{(1+\rho)^{s}}-\sum_{s=0}^{\infty} \frac{d I_{t+s}}{(1+\rho)^{s}}+\tau \phi \sum_{s=0}^{\infty} \frac{d I_{t+s}+d K_{t-1+s}^{T}}{(1+\rho)^{s}}\right)
$$

The first of these sums is simple to rearrange, the second sum simply equals one, as there is no investment or disinvestment in future periods, and the third sum is the present discounted value of depreciation allowances $A$ :

$$
R^{R E}=\gamma\left(\frac{(p+\delta)(1+\pi)(1-\tau)}{\rho-\pi+\delta(1+\pi)}-1+A\right)
$$

The financial effects are also affected. In case of new equity they can be easily derived by assuming a one-time issue of new equity at the amount of the net of tax cost of the asset, i.e., $d N_{t}=1-\tau \phi$ and $d N_{t+i}=0 \forall i>0$. Substituting this into (3) and (2) gives:

\footnotetext{
${ }^{7}$ An EATR based on such indefinite investment is also described in Sorensen (2004). This, however, is defined in more general terms and in continuous time, so that it does not allow a direct application to the DevereuxGriffith EATR.
} 


$$
F^{N E}=\sum \frac{\gamma D_{t+s}-d N_{t+s}}{(1+\rho)^{s}}=(\gamma-1)(1-\tau \phi)
$$

For debt-financed projects, there are a number of reasonable assumptions. A firm could issue one-period debt and then refinance indefinitely, i.e. paying only interest but no principal. However, given that the asset depreciates, this assumption would imply increased leverage over time, which would have a tax benefit unrelated to the investment. We assume therefore instead that the firm issues debt at the net of tax cost of the asset in the first year. In following years it only issues debt equivalent to the initial issue less net depreciation so as to keep a stable debt-asset ratio, i.e., $d B_{t}=1-t \phi$ and $d B_{t+i}=(1-t \phi)((1-\delta)(1+\pi))^{i} \forall i \geq 0$. Substituting these yields:

$$
F^{D}=\frac{\gamma(1-\tau \phi)(\rho-i(1-\tau))}{\rho+\delta(1+\pi)-\pi}
$$

As before, the cost of capital is obtained by setting equation (11) (plus any financing effect) equal to zero. It turns out that the result is identical to the one under the Devereux-Griffith tax rate (equation (6)), so that the EMTR is the same under both approaches.

Moreover, provided interest is free of personal income tax or the analysis abstracts from such taxation, the EATR for an indefinite investment project is also equal to Devereux-Griffith EATR. ${ }^{8}$ In other words, the treatment of excess depreciation chosen by Devereux and Griffith ensures that the assumption of a one-period perturbation becomes irrelevant. This in turn implies that countries, such as the U.K. that do allow pooled depreciation achieve neutrality between the choice to invest for a long or short horizon. If, however, a researcher specifically wanted to study short-term investment in a country that taxes excess depreciation on the sale of an asset, then the Devereux-Griffith rate would be misleading. However, many users of EATRs were probably unaware of both the excess depreciation and the one-period capital stock perturbation assumptions, and treated EATRs as if they applied to longer term investments. Provided personal interest taxes were excluded, they were right in doing so. And usually such taxes are excluded, because it is not clear how relevant they are: Domestic investors may be able to avoid them, e.g., by investing through a pension fund and international investors will face different interest rates anyway.

To give an idea of the differences between the approaches in practice, the following tables show a few tax rates for six advanced economies. Table 1 shows effective tax rates when personal taxes are excluded. As the permanent investment tax rates are identical to the Devereux-Griffith ones in this case, they are not shown. The table shows that effective tax

\footnotetext{
${ }^{8}$ Remember that without interest taxation, $\rho=i=r(1+\pi)+\pi$. Substituting this into (4) and (1) yields the same result as substituting into (11) and (9). Taxes on dividends and capital gains have the same effect on both tax rates and need not be excluded.
} 
rates for immediately taxed depreciation are higher than the standard Devereux-Griffith rates, which is not surprising, given that more stringent taxation is assumed. They are also less sensitive to the profit rate, which can be explained by the fact that the benefit of the depreciation allowance, which in the Devereux-Griffith case is relatively more important for less profitable firms, is very small in the adjusted rates, as it is taken back after just one year. While the ranking of countries is unaffected in this table, this does not hold in general.

Table1. Effective Tax Rates in Selected Advanced Economies, 2005, Excluding Personal Taxes

(In percent)

\begin{tabular}{lcccccc}
\hline \multicolumn{1}{c}{ Country } & $\begin{array}{c}\text { Statutory Tax } \\
\text { Rate }\end{array}$ & $\begin{array}{c}\text { PDV of Depr. } \\
\text { Allowances/ } \\
\text { Tax Rate }\end{array}$ & EMTR & $\begin{array}{c}\text { EMTR, } \\
\text { Excess Depr. } \\
\text { Taxed }\end{array}$ & EATR & $\begin{array}{c}\text { EATR, } \\
\text { Excess Depr. } \\
\text { Taxed }\end{array}$ \\
\hline Canada & 35.6 & 73.2 & 24.8 & 38.6 & 28.4 & 38.0 \\
France & 33.8 & 77.5 & 20.4 & 33.0 & 25.4 & 33.2 \\
Germany & 38.3 & 71.0 & 28.6 & 40.0 & 31.5 & 39.7 \\
Japan & 39.7 & 73.3 & 28.2 & 39.8 & 31.7 & 39.8 \\
UK & 30 & 73.3 & 20.3 & 30.1 & 23.9 & 30.1 \\
USA & 39.3 & 78.5 & 23.6 & 38.2 & 29. & 38.4 \\
\hline
\end{tabular}

Source: Author's calculation based on updated data from Devereux, Griffith and Klemm (2002), available from http://www.ifs.org.uk/publications.php?publication_id=3210.

Notes: Calculated for an investment in plant and machinery, financed by retained earnings. Assumptions: inflation: 3.5 percent, real rate of interest: 10 percent, economic depreciation: 12.25 percent, profit rate (EATR): 20 percent.

Table 2 shows effective taxes including the effects of personal taxes. Although the resulting tax rates may not be informative, for the reasons given above, the table serves as an illustration of the differences. First, note the seemingly counterintuitive reduction in tax rates compared to the case where personal taxes were excluded. This is explained by the fact that the effective tax rate approach is built on the assumption that investors discount profits at the net interest rate. Adding personal taxes on interest therefore increases the present discounted after-tax value of a project. The resulting tax rates differ quite a lot across assumptions. While the ranking is unaffected for these particular countries, in general it need not be the same. 
Table 2. Effective Tax Rates in Selected Advanced Economies, 2005, Including Personal Taxes

(In percent)

\begin{tabular}{lcccccc}
\hline Country & $\begin{array}{c}\text { EMTR, } \\
\text { Devereux- } \\
\text { Griffith }\end{array}$ & $\begin{array}{c}\text { EMTR, } \\
\text { Permanent } \\
\text { Investment }\end{array}$ & $\begin{array}{c}\text { EMTR, } \\
\text { Excess Depr. } \\
\text { Taxed }\end{array}$ & $\begin{array}{c}\text { EATR, } \\
\text { Devereux- } \\
\text { Griffith }\end{array}$ & $\begin{array}{c}\text { EATR, } \\
\text { Permanent } \\
\text { Investment }\end{array}$ & $\begin{array}{c}\text { EATR, } \\
\text { Excess Depr. } \\
\text { Taxed }\end{array}$ \\
\hline Canada & -80.0 & -80.0 & -33.8 & 0.4 & -14.3 & 7.0 \\
France & -67.7 & -67.7 & -31.6 & 1.2 & -11.1 & 6.9 \\
Germany & -67.6 & -67.6 & -28.7 & 14.4 & 4.1 & 19.0 \\
Japan & 10.7 & 10.7 & 26.6 & 23.0 & 20.9 & 30.4 \\
UK & -66.6 & -66.6 & -38.3 & -14.4 & -30.6 & -8.7 \\
USA & -41.5 & -41.5 & -07.1 & 9.0 & 0.3 & 16.2 \\
\hline
\end{tabular}

Source: Author's calculation based on updated data from Devereux, Griffith and Klemm (2002), available from http://www.ifs.org.uk/publications.php?publication id=3210.

Notes: Calculated for an investment in plant and machinery, financed by retained earnings. Assumptions: inflation: 3.5 percent, real rate of interest: 10 percent, economic depreciation: 12.25 percent, profit rate (EATR): 20 percent.

\section{TAX Holidays}

Given the infinite horizon, it is now possible to allow for time-varying tax rates. ${ }^{9}$ Possible applications would be cases in which firms already know that tax rates will be reduced or increased in the future. A special case, and one that is of particular interest in many countries, is a limited tax holiday, i.e., a period of $Y$ years during which tax rates are set to zero.

The model above can be very easily adapted for this. The first sum of equation (10) needs to reflect the tax-free years:

$$
\begin{aligned}
& \sum_{s=1}^{Y} \frac{(p+\delta)(1+\pi)^{s}(1-\delta)^{s-1}}{(1+\rho)^{s}}+\sum_{s=Y+1}^{\infty} \frac{(p+\delta)(1-\tau)(1+\pi)^{s}(1-\delta)^{s-1}}{(1+\rho)^{s}} \\
& =\frac{(p+\delta)(1+\pi)}{\rho-\pi+\delta(1+\pi)}\left(1-\tau\left(\frac{(1-\delta)(1+\pi)}{1+\rho}\right)^{Y}\right)
\end{aligned}
$$

\footnotetext{
${ }^{9}$ A previous illustration of the effects of a tax holiday on a measure of the EMTR is provided in Bond (1981).
} 
Equally, the present discounted value of depreciation allowances has to be adapted, as allowances during tax holiday years are worthless to the firm. ${ }^{10}$ An exception to this would be a country that allowed unused depreciation allowances to be carried forward, which is, however, rare. ${ }^{11}$ Putting this all together, we obtain:

$$
R=\gamma\left(\frac{(p+\delta)(1+\pi)}{\rho-\pi+\delta(1+\pi)}\left(1-\tau\left(\frac{(1-\delta)(1+\pi)}{1+\rho}\right)^{Y}\right)-1+A\right)+F
$$

The financial effects also need to be adjusted. For new equity this is very simple: as there is no depreciation allowance in the first year anymore, equity up to the value of the entire investment needs to be issued. Hence the financial effect simplifies to: $F^{N E}=(\gamma-1)$. If the tax holiday also covers personal taxes, then it simplifies further to zero.

For debt finance, the previous effect needs to reflect that interest deductibility is worthless during the years of the tax holiday:

$$
F^{D}=\gamma \frac{\rho-i+\tau i\left(\frac{(1-\delta)(1+\pi)}{1+\rho}\right)^{Y}}{\rho-\pi+\delta(1+\pi)}
$$

To illustrate the effect of a tax holiday, consider a hypothetical country with a tax rate of 30 percent and depreciation allowance of 25 percent (declining balance), which introduces an eight-year tax holiday. Using the approach developed here, the effective tax rates can be easily calculated. They will, however, only apply to an investment taking place in the first year of the tax holiday. In the following year, any new investment will face an effective tax rate for a seven-year holiday only. Figure 1 illustrates the development of effective tax rates over the course of a tax holiday.

${ }^{10}$ Assuming no carry-forward of unused allowances, we have $A=\tau \phi \frac{1+\rho}{\rho+\phi}\left(\frac{1-\phi}{1+\rho}\right)^{Y}$ for declining-balance and $A=\frac{\tau \phi(1+\rho)}{\rho}\left(\left(\frac{1}{1+\rho}\right)^{Y}-\left(\frac{1}{1+\rho}\right)^{1 / \phi}\right) \forall Y \leq \frac{1}{\phi}$ for straight-line depreciation. If methods are switched or rates change, the formulae are more complicated. Up to three rate and method changes are taken into account in the program calculating the tax rates.

\footnotetext{
${ }^{11}$ Note that the depreciation allowance is worthless because of the zero tax rate, not because of tax exhaustion. Hence, loss carry forward provisions will not help (unless the investor is making a cumulative loss over the entire holiday).
} 
Figure 1: Effective tax rates under tax holidays

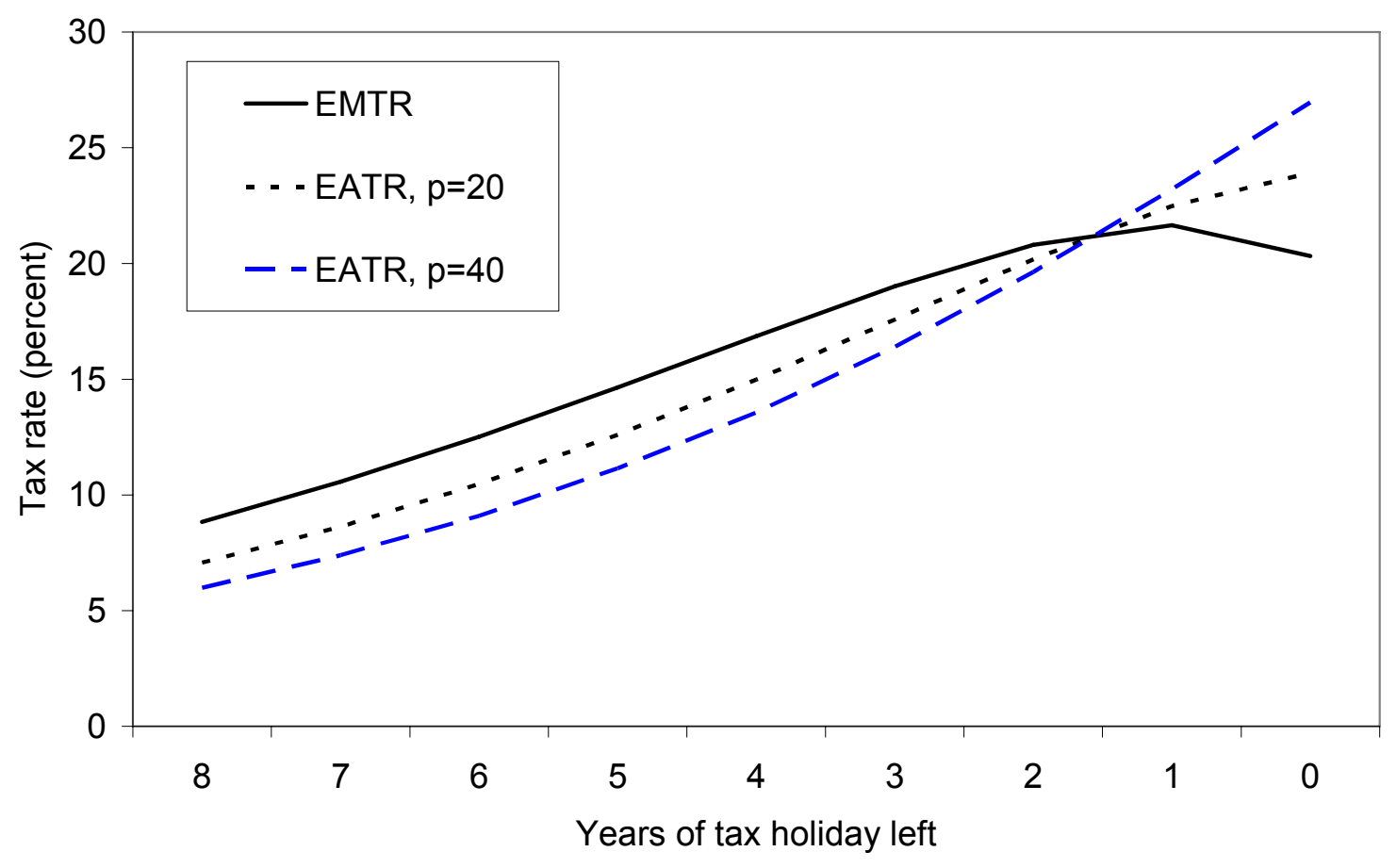

Source: Author's calculation.

Notes: Calculated for an investment in plant and machinery, financed by retained earnings. Assumptions: inflation: 3.5 percent, real rate of interest: 10 percent, economic depreciation: 12.25 percent, personal taxes excluded.

As shown in Figure 1, the tax holiday unsurprisingly reduces the effective tax rates tremendously, especially at high rates of profitability. A country that introduces such a holiday will therefore increase its attractiveness as a place to invest significantly, especially for a large profitable one-time investment - even if this investment is expected to last for much longer than the holiday. The tax holiday will, however, be less attractive for repeated investment, as would be necessary in industries, which are expected to grow or where capital replacements will be necessary, because tax rates increase as the tax holiday runs out. In the final years of the tax holiday, it is even possible that some effective tax rates (such as the EMTR in Figure 1) exceed those of firms without holidays. This effect, which was previously derived by Mintz (1990) arises for low-profitability projects if statutory depreciation allowances exceed true economic depreciation, because in this case the loss of the allowance may outweigh the benefit of a zero tax-rate. The tax holiday then has the ironic consequence of discouraging some investment.

Clearly, the exact shape of the effective tax rates presented in Figure 1 depends on the assumptions made. A higher discount or inflation rate makes the tax holiday even more beneficial, and at sufficiently high rates the EMTR does not peak before the expiration of the holiday anymore. A higher depreciation allowance relative to true economic depreciation 
makes the tax holiday less attractive and can lead to effective tax rates peaking even earlier in the tax holiday.

Tax holidays are controversial, both for the reasons that follow from the analysis above and those that go beyond what can be included in an effective tax rate measure, such as their possible encouragement of rent-seeking behavior. As others have discussed these in detail (see Zee, Stotsky and Ley, 2002), this will not be repeated here. But effective tax rates facilitate the comparison of different possible tax reforms, and given that a frequent advice by economists is to increase investment allowances instead of introducing tax holidays, we will analyze this choice. Specifically, Figure 2 compares tax holidays to the highest possible increase of depreciation allowances to 100 percent in the first year, which is equivalent to a cash flow tax (of the R-base variety, see Meade 1978).

Figure 2: Tax holidays versus a cash flow tax

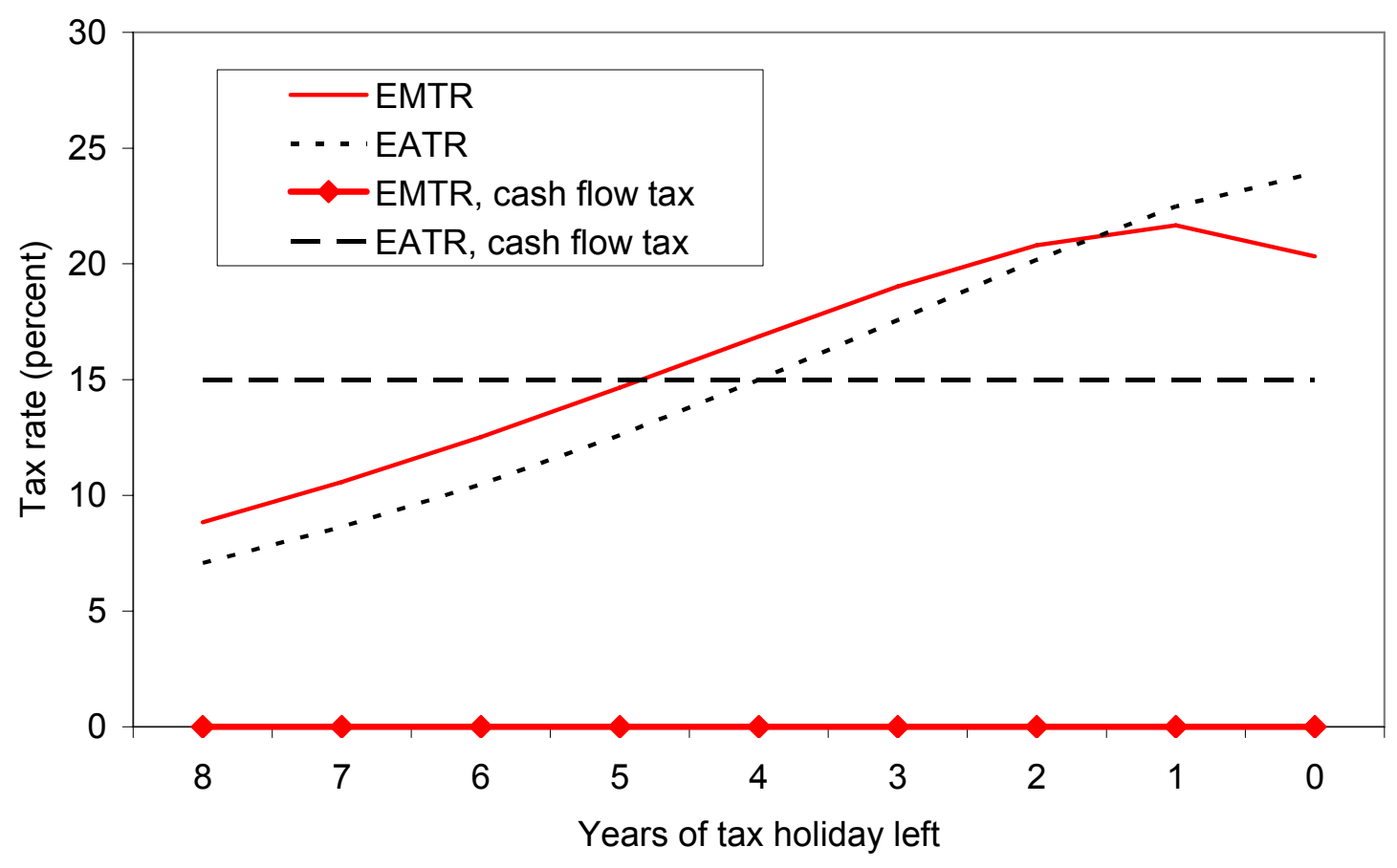

Source: Author's calculation.

Notes: Calculated for an investment in plant and machinery, financed by retained earnings. Assumptions: inflation: 3.5 percent, real rate of interest: 10 percent, economic depreciation: 12.25 percent, personal taxes excluded.

As shown in Figure 2, the benefits of a tax holiday cannot be beaten by even the most generous depreciation rules for profitable investments. For less profitable investments, however, the cash flow tax leads to the well-known result of a zero EMTR, so that the system is neutral to taxation in that no project which would break even in the presence of taxation will turn loss-making. And even for profitable projects, the benefit of a generous depreciation system would continue to apply for additional or replacement investment, while the effective 
tax rates under the tax holiday increase soon. Where exactly (and whether) the EATRs under both reform scenarios cross depends on the specific assumptions. The higher the expected profitability, the greater the benefit of the tax holiday relative to generous depreciation.

\section{Conclusion}

Effective marginal and average tax rates have become ubiquitous in discussions of tax reforms. It is, however, rarely mentioned that the most used measure, as developed by Devereux and Griffith (2003) is based on the assumption of a one-period perturbation in the capital stock. This paper has shown, that this matters less than one may at first suspect. Thanks to the way excess depreciation allowances on sold assets is treated (pooled depreciation), the Devereux-Griffith EATR is indeed a good indicator of the taxes faced by long-term investment. If, as usual, analysis abstracts form personal income taxes (or at least taxes on interest), the Devereux-Griffith tax rates are exactly identical to the ones proposed here, which are based on an indefinite investment. This finding, moreover, demonstrates that pooled depreciation leads to neutrality in firm's decision as to how long to hold an asset.

Even though the infinite-horizon effective tax rates developed here are identical under most circumstances to those defined by Devereux and Griffith, the extension does have practical advantages. In particular, it allows the calculation of effective tax rates under tax holidays, or more generally, under changing tax rates. Applied to tax holidays, the infinite-horizon tax rates can be used to illustrate how their benefits run out over the course of the holiday, and how they can even discourage investment in the final years. 


\section{References}

Bond, Eric, 1981, "Tax Holidays and Industry Behavior," Review of Economics and Statistics, Vol. 63(1), pp. 88-95.

Devereux, Michal P., 2004, "Measuring Taxes on Income from Capital”, in: Sorensen, PeterBirch (ed.) "Measuring the Tax Burden on Capital and Labor," Cambridge, MA: MIT Press, pp. 35-71.

Devereux, Michael P. and Rachel Griffith, 2003, "Evaluating Tax Policy Decisions for Location Decisions," International Tax and Public Finance, Vol. 10, pp. 107-26.

Devereux, Michael P., Rachel Griffith and Alexander Klemm, 2002, "Corporate income tax reforms and international tax competition," Economic Policy, Vol. 17(35), pp. 451-95.

Devereux, Michal P. and Alexander Klemm, 2004, "Measuring Taxes on Income from Capital: Evidence from the United Kingdom," in: Sorensen, Peter-Birch (ed.) "Measuring the Tax Burden on Capital and Labor", Cambridge, MA: MIT Press, pp. 73-91.

King, M. and D. Fullerton, 1984, "The Taxation of Income from Capital: A Comparative Study of the US, U.K., Sweden and W. Germany-Comparisons of Effective Tax Rates," Chicago: University of Chicago Press.

Klemm, Alexander, 2007, "Allowances for Corporate Equity in Practice," CESifo Economic Studies, Vol. 53(2), pp. 229-62.

Meade, James, 1978, “The Structure and Reform of Direct Taxation,” London: Allen and Unwin.

Mintz, Jack M., 1990, "Corporate Tax Holidays and Investment," The World Bank Economic Review, Vol. 4 (3), pp. 81-102.

Nicodeme, Gaetan, 2001, "Computing Effective Corporate Tax Rates: Comparisons and Results," Economic Paper 153, DG Economic and Financial Affairs, European Commission.

Organisation for Economic Co-operation and Development, 2001, "Tax Ratios: A Critical Survey," Tax Policy Studies 5 (Paris: Organisation for Economic Co-operation and Development).

Sorensen, Peter-Birch, 2004, "Measuring Taxes Capital and Labor: An Overview of the Issues," in Measuring the Tax Burden on Capital and Labor, ed. by Sorensen, Peter-Birch (Cambridge, MA: MIT Press), pp. 1-33. 
Zee, Howell H., Janet G. Stotsky, and Eduardo Ley, 2002, "Tax Incentives for Business Investment: A Primer for Policy Makers in Developing Countries," World Development, Vol. 30(9), pp. 1497-516. 